\title{
Pengembangan dan Aplikasi Sistem Informasi Usaha Kesehatan Sekolah (UKS) di Kabupaten Purwakarta
}

\author{
Johari* $^{*}$
}

\begin{abstract}
Abstrak
Pencapaian kegiatan Usaha Kegiatan Sekolah dari Standar Pelayanan Minimal di Kabupaten Purwakarta, tahun 2005 masih jauh dibawah target standar pelayanan minimal secara nasional. Cakupan tersebut meliputi deteksi dini tumbuh kembang anak balita dan prasekolah (74,57\%), pemeriksaan kesehatan siswa oleh tenaga terlatih $(61,82 \%)$ pelayanan kesehatan remaja $(51,17 \%)$. Penelitian ini bertujuan membangun sistem informasi UKS di Kabupaten Purwakarta dalam upaya mendukung pelaksanaan manajemen UKS Metode yang digunakan berdasarkan System Development Life Cycle (SDLC) yang meliputi tahap perencanaan, analisis, perancangan dan implementasi sistem/ uji coba prototype. Pengumpulan data dan informasi dilakukan melalui wawancara mendalam, telah dokumen dan observasi. Unit kerja yang menjadi obyek penelitian adalah Dinas kesehatan, Puskesmas Jatiluhur, Puskesmas Campaka dan Puskesmas Plered di Kabupaten Purwakarta. Penelitian ini menghasilkan prototipe Sistem Informasi Usaha Kesehatan Sekolah (UKS) di Kabupaten Purwakarta yang membantu pelaksanaan manajemen UKS sehingga dapat meningkatkan kualitas laporan dan pencapaian kegiatan UKS. Untuk dapat berjalan baik dan sinambung, pelaksanaan sistem informasi ini membutuhkan komitmen dan kebijakan yang kuat, aturan organisasi pelaksana yang jelas, motivasi pelaksana yang kuat dan dukungan dana yang sinambung.
\end{abstract}

Kata kunci : Usaha kegiatan sekolah, sistem informasi.

\begin{abstract}
The coverage of Health School Program (Usaha Kegiatan Sekolah/UKS) in Purwakarta District in 2005 was far below the target of national Minimal Service Standar. The indicators include early detection of growth and development of underfives and pre-schoolers (74.57\%), students health examination by health personnel $(61.82 \%)$, and teenagers health service (51.17\%). This study aimed at developing information system of UKS in Purwakarta district to support the implementation of UKS management. Method used was based on System Development Life Cycle (SDLC) including planning, analysis, design, and system implementation/prototype testing. Data and information collection was done through in-depth interview, document review, and observation. Working unit being study object was Health Office, jatiluhur, Campaka, and Plered Health Centers, all located in Purwakarta district. This study resulted in prototype of UKS system that support the implementation of UKS management as to improve the quality of report and UKS coverage. To run well and to be sustained, this information system needs commitment and strong policy, clarity in rules and regulations, high motivation of personnel, and continuous fund suppport.
\end{abstract}

Key words : School health program, information system 
Anak usia sekolah (6-21 tahun) merupakan sasaran pembinaan kesehatan yang sangat strategis untuk mempersiapkan generasi penerus yang sehat, mandiri, produktif, berkualitas, tangguh dan mampu bersaing secara global. ${ }^{1}$ Namun, anak usia sekolah merupakan kelompok yang rawan karena sedang mengalami masa pertumbuhan fisik yang sangat cepat dan tidak seimbang dengan perkembangan mental dan sosial. Hal ini akan berpengaruh pada perilaku, sehingga pendidikan formal di sekolah dan pendidikan informal di keluarga atau lingkungannya akan berperan paling dominan membentuk perilaku anak. ${ }^{2}$

Saat ini, masalah kesehatan anak usia sekolah pada tingkat sekolah dasar sebagian besar terkait dengan perilaku hidup bersih dan sehat seperti kebersihan perorangan. Sementara, remaja (10-19 tahun) lebih terkait dengan perilaku hidup berisiko seperti seks pranikah, kehamilan tak diinginkan, pengguguran kandungan (aborsi), penyakit menular seksual termasuk HIV/AIDS dan penyalahgunaan NAPZA (narkotika, alkohol, psikotropika dan zat adiktif lainnya). ${ }^{2}$

Jumlah usia anak sekolah berdasarkan SDKI 1997, tingkat partisipasi anak usia sekolah 6-14 tahun (90\%), 15-19 tahun (50\%) dan untuk usia 20-29 tahun (9\%). Jumlah dan proporsi anak usia sekolah sangat besar diperkirakan sepertiga dari jumlah penduduk Indonesia ( \pm 70 juta jiwa). ${ }^{3}$ Di Kabupaten Purwakarta tahun 2004, jumlah anak sekolah tercatat yaitu murid TK 2.692 anak, SD 98.157 anak, SLTP 26.268 anak, SMA 8.664 anak dan SMK 8.352 anak. Sedangkan jumlah anak pada kelompok umur 5-9 tahun 65.685 anak, umur 10-14 tahun 72.546 anak, dan 15-19 tahun 79.685 anak sehingga jumlah anak usia sekolah mencapai 217.916 anak atau $28,41 \%$ dari total jumlah penduduk Kabupaten Purwakarta. ${ }^{4}$ Memperhatikan jumlah anak usia sekolah di atas, anak usia sekolah merupakan potensi pengembangan dan pelayanan kesehatan.

Untuk memantau kesehatan anak usia sekolah, Dinas Kesehatan melalui puskesmas melakukan kegiatan penjaringan kesehatan anak sekolah. Hasil kegiatan tersebut dilaporkan dalam bentuk laporan kegiatan hasil penjaringan dan laporan bulanan kegiatan UKS (LB4). Laporan hasil kegiatan penjaringan dikirimkan kepada pengelola program UKS seksi pelayanan kesehatan dasar Dinas Kesehatan Kabupaten. Sedangkan laporan kegiatan UKS LB4, digabungkan dengan laporan SP3 lainnya dikirimkan kepada seksi monitoring dan data informasi kesehatan.

Hasil evaluasi kegiatan UKS tahun 2004, menunjukan hanya 413 dari 787 sekolah $(52,48 \%)$ yang melaksanakan penjaringan kesehatan di Kabupaten Purwakarta sehingga masih terdapat sekolah yang belum terpantau kesehatan muridnya. Data Sistem Pencatatan dan Pelaporan Puskesmas (SP3) tahun 2005 terdapat penyakit ISPA sebanyak 1.406 murid, penyakit gigi 7.238 murid, penyakit kulit 719 murid, penyakit mata 125 murid, penyakit kusta 3 murid dan penyakit TB Paru 389 murid. Dari hasil survey yang dilakukan oleh Yayasan Kusuma Buana dari 3000 anak sekolah yang diperiksa, hampir separuhnya menderita anemia. Hal ini berarti satu dari dua anak usia sekolah menderita anemia. Berdasarkan hasil penjaringan kesehatan pada anak usia sekolah, di Kabupaten Purwakarta, ditemukan 376 kasus anemia $(1,02 \%)$. Hasil penjaringan tersebut jauh lebih kecil daripada hasil survey yang dilakukan oleh Yayasan Kusuma Buana. Oleh sebab itu, dibutuhkan survey untuk mengetahui prevalensi kasus anemia di Kabupaten Purwakarta.

Berdasarkan data laporan tahun 2004, sekolah yang mempunyai guru UKS adalah 65,69\% sekolah. Sedangkan jumlah sekolah yang memiliki kader UKS termasuk dokter kecil hanya 57,43\%. Standar/paket pelayanan UKS tahun 2004 menunjukan hanya 72 sekolah $(9,15 \%)$ yang mencapai katagori optimal dan tidak ada sekolah yang mencapai katagori paripurna.

Sistem informasi UKS di Kabupaten Purwakarta saat ini masih berjalan secara manual yang ditandai dengan pencatatan dan pelaporan yang belum terdokumentasikan secara baik. Hal ini disebabkan oleh sistem pencatatan dan pelaporan tidak lengkap, belum ada kesamaan format pencatatan dan pelaporan, pengolahan dan analisis data dilakukan secara manual, belum terbentuk basis data dan informasi yang dihasilkan, belum berdasarkan indikator. Untuk itu, perlu dikembangkan sistem informasi UKS yang diharapkan dapat membantu pelaksana program UKS tingkat kabupaten dalam melakukan pengolahan dan analisis program UKS. Sistem informasi UKS yang akuntabel tersebut dapat dimanfaatkan dalam evaluasi program, bahan pengambilan keputusan dan advokasi untuk peningkatan kinerja dan mutu program UKS. Penelitian ini bertujuan terbangunnya sistem informasi UKS di Kabupaten Purwakarta dalam mendukung pelaksanaan manajemen UKS.

\section{Metode}

Pengembangan sistem database UKS menggunakan pendekatan kualitatif dengan metode wawancara mendalam, studi dokumen, observasi dan melalui tahap pengembangan sistem yang disebut System Development Life Cycle (SDLC). Pada pengembangan sistem database UKS, entitas dari sistem informasi Usaha Kesehatan Sekolah digambarkan sebagai berikut : (a) Entitas sumber yaitu di puskesmas adalah petugas UKS yang melakukan kegiatan di SD UKS. Laporan dari puskesmas merupakan entitas sumber untuk dinas kesehatan. Entitas proses adalah sebuah interaksi di antara entitas sumber dengan melakukan pengumpulan, pengolahan, 
dan analisis untuk menghasilkan informasi yang dialirkan ke entitas tujuan. Entitas proses adalah di Puskesmas dan di bidang pelayanan kesehatan (yankes) seksi pelayanan kesehatan dasar (yankesdas) di Dinas Kesehatan Kabupaten Purwakarta. Entitas tujuan yang berfungsi menerima informasi meliputi kepala dinas, kepala bidang pelayanan kesehatan, dan seksi pelayanan kesehatan dasar.

\section{Hasil}

Luas wilayah Kabupaten Purwakarta 971,172 Km² atau sekitar 2,81\% dari luas wilayah Propinsi Jawa Barat yang terletak diantara 107030'-107040' Bujur Timur dan 6025'-6045' Lintang Selatan. Jumlah penduduk Kabupaten Purwakarta tahun 2006 tercatat sebanyak 798.219 jiwa kelompok umur anak usia sekolah yaitu 5-19 tahun sebanyak 220.003 anak atau $27,56 \%$.

Jumlah sarana kesehatan puskesmas meliputi satu rumah sakit pemerintah daerah dan rumah sakit swasta. Di Kabupaten Purwakarta, sebagian besar tenaga kesehatan $(50,95 \%)$ bekerja di puskesmas dan puskesmas pembantu, sekitar 43,96\% bekerja di RSUD Bayu Asih dan hanya 5,09\% yang bekerja di dinas kesehatan. Pencapaian SPM kegiatan UKS meliputi Cakupan Deteksi Dini Tumbuh Kembang Anak Prasekolah $(74,57 \%)$ dibawah target SPM (90\%). Cakupan Pemeriksaan Kesehatan siswa SD dan setingkat oleh tenaga kesehatan atau tenaga terlatih/guru UKS/dokter kecil $(61,82 \%)$ jauh dibawah target 100\%. Cakupan Pelayanan Kesehatan Remaja ( 51,17\%) dari target $80 \%$.

Keadaan UKS di Kabupaten Purwakarta, tahun 2006 terdapat 684 sekolah dari 830 sekolah $(82,4 \%)$ yang telah mencapai sekolah UKS, 579 sekolah $(84,6 \%)$ dengan guru UKS, 486 sekolah $(71,1 \%)$ dengan dana sehat dan 461 sekolah $(67,4 \%)$ dengan TP UKS. UKS yang mencapai paket optimal dan paripurna berdasarkan tingkatan pendidikan masih sangat kecil (0-17,5\%) pada paket optimal dan 0-1,8\% pada paket paripurna. Hasil penjaringan kesehatan UKS tahun 2006 menunjukkan terlihat jumlah sekolah diperiksa berkisar antara 45,61 - 76,53\% dengan penjaringan kesehatan tertinggi pada SD/MI $(76,53 \%)$ dan terendah pada SMP/MTS.

\section{Perencanaan Sistem}

Pada tahap ini, dilakukan identifikasi tujuan yang harus dicapai dan cakupan sistem yang akan dikembangkan serta peluang pengembangan sistem berdasarkan analisis kelayakan ekonomi, teknis dan organisasi. Dari hasil wawancara mendalam didapatkan bahwa secara ekonomis sistem informasi UKS di Kabupaten Purwakarta layak untuk dikembangkan mengingat pada saat ini sistem informasi yang ada dengan manual sering menghadapi banyak kendala seperti tulisan yang sulit dibaca, kesalahan penjumlahan, perbedaan data yang dilaporkan. Sistem informasi UKS yang baru diharapkan dapat mengurangi kendala pelaporan UKS.

Secara teknis, berdasarkan hasil telaah dokumen dan observasi didapatkan bahwa perangkat keras dan penunjang pengelolaan sistem untuk Program UKS di Kabupaten Purwakarta telah tersedia dan tenaga sudah memadai dalam mengelola sistem yang akan dikembangkan. Berdasarkan hasil wawancara dan telaah dokumen diketahui bahwa Pengelola Program UKS di Kabupaten Purwakarta meliputi seorang pengelola program UKS tingkat kabupaten dengan pendidikan D-3 Kebidanan dan di puskesmas pengelola program UKS ditangani oleh perawat gigi, dokter dan perawat.

\section{Analisis Sistem \\ Komponen Input : \\ Sumber Daya}

Sumber daya tenaga pelaksana Sistem Informasi Program UKS di kabupaten masih terbatas. Sarana pendukung sudah tersedia, perangkat keras dan perangkat lunak komputer dengan spesifikasi yang memadai. Pengumpulan data : Data yang terkumpul hasil laporan di puskesmas sering terlambat dan masih kurang lengkap. Format yang digunakan masih belum seragam dan tidak semua petugas memahami pengisian format pencatatan dan pelaporan UKS.

\section{Komponen Proses : \\ Pengolahan Data}

Proses pengolahan data masih dilakukan secara manual dengan memindahkan data dari catatan atau buku visum atau buku kegiatan UKS kepada rekapitulasi laporan yang dikirimkan ke kabupaten.

\section{Penyajian Data}

Penyajian data masih terbatas pada laporan rekapitulasi hasil penjaringan kesehatan dan keadaan UKS, sebagian puskesmas telah menyajikan data dalam laporan tahunan tetapi data tersebut belum disajikan sebagai indikator program UKS dalam bentuk grafik.

\section{Masalah Output : \\ Pemanfaatan}

Output yang dihasilkan berupa laporan penjaringan UKS dan keadaan UKS. Pada laporan penjaringan dapat diuraikan menjadi cakupan pemeriksaaan berdasarkan sekolah dan murid, status gizi, status $\mathrm{Hb}$, tes kesegaran jasmani, status/hasil pemeriksaan dan jenis penyakit yang ditemukan. Dari laporan keadaan UKS, akan didapatkan 
Tabel 1. Unsur-unsur Manajemen Peluang Pengembangan Sistem

\begin{tabular}{|c|c|c|}
\hline Unsur & Yang Tersedia & Peluang Pengembangan \\
\hline 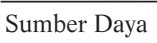 & Seorang Pengelola UKS kabupaten, berpendidikan D-3 & Melaksanakan pelatihan untuk meningkatkan keterampilan. \\
\hline Manusia & Kebidanan, 2 tahun memegang program UKS & Jika mungkin, diadakan rekrutan operator khusus pengolah data. \\
\hline Sarana & $\begin{array}{l}\text { Satu unit Komputer dengan spesifikasi Processor } \\
\text { Pentium IV }\end{array}$ & $\begin{array}{l}\text { Komputer yang ada kini lebih dimanfaatkan untuk pengembangan } \\
\text { sistem. }\end{array}$ \\
\hline Dana & $\begin{array}{l}\text { Belum ada dana pengembangan sistem, dana kegiatan } \\
\text { program dari APBD Kabupaten/ Propinsi, serta APBN }\end{array}$ & $\begin{array}{l}\text { Anggaran operasional \& pemeliharaan sistem diusulkan pada } \\
\text { APBD kabupaten. }\end{array}$ \\
\hline Teknologi & $\begin{array}{l}\text { Program Microsoft Office termasuk MS Excel (tidak } \\
\text { berupa base) }\end{array}$ & $\begin{array}{l}\text { Software khusus digunakan untuk mendukung pelaksanaan data } \\
\text { kegiatan program. Lebih baik dibuat instalasi jaringan seperti } \\
\text { WLAN, LAN atau untuk pengiriman data sehingga informasi } \\
\text { terdistribusi cepat. }\end{array}$ \\
\hline Manajemen & Mendukung informasi yang akurat, relevan dan cepat. & $\begin{array}{l}\text { Manajemen sangat mendukung pengembangan sistem informasi } \\
\text { Program UKS untuk meningkatkan kinerja dan memudahkan } \\
\text { evaluasi/perencanaan program. }\end{array}$ \\
\hline
\end{tabular}

Gambar 1. Data Flow Diagram (DFD) Level Contex

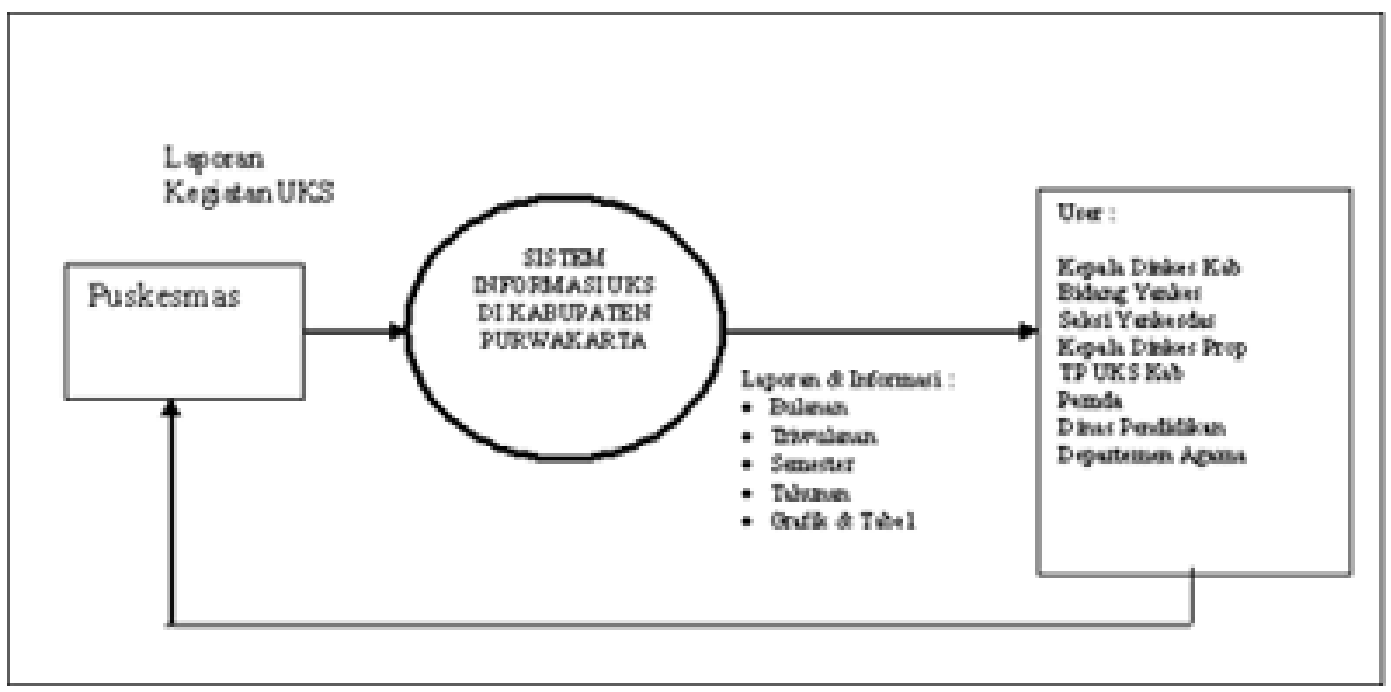

cakupan sekolah dan murid UKS, kader dan guru UKS, cakupan dana sehat, cakupan TP UKS, sarana KIT UKS dan paket pelayanan UKS. Namun, beberapa angka cakupan tidak dapat dihitung karena data yang dilaporkan oleh puskesmas tidak tersedia. Kesulitan ini disebabkan oleh tidak tersedia data register UKS untuk memenuhi data yang dibutuhkan untuk menghitung cakupan tersebut.

\section{Mekanisme Umpan Balik}

Mekanisme umpan balik belum dilakukan secara rutin dan umumnya hanya dilakukan lewat telepon apabila ditemukan kejanggalan data yang dikirimkan atau terlambat.

\section{Peluang Pengembangan Sistem}

Peluang pengembangan Sistem Informasi Program Program UKS di Kabupaten Purwakarta dapat dilihat pada tabel 1.

\section{Rancangan Sistem Informasi}

Rancangan sistem informasi ini dimulai dari merancang model, mengembangkan sistem organisasi dan menetapkan teknologi yang digunakan. Sistem informasi yang dikembangkan diharapkan mampu menghasilkan informasi Program UKS yang bermanfaat bagi para stake 
Gambar 2. Data Flow Diagram Level 0

\section{OFD LEVEL 0}

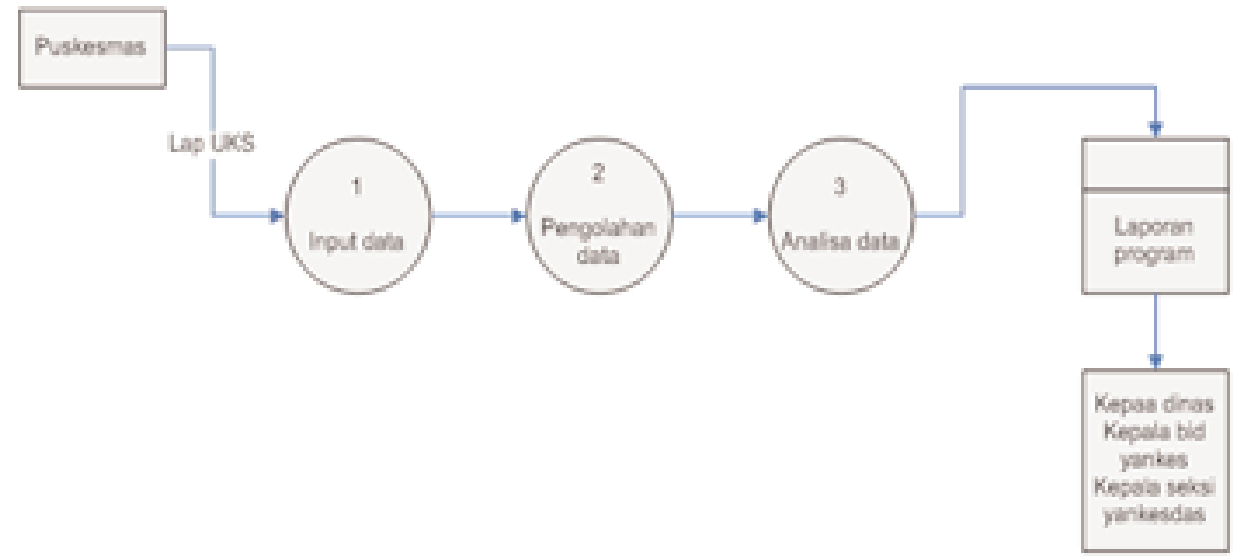

holders dalam membuat rencana, monitoring dan evaluasi program dan pihak-pihak yang membutuhkan informasi yang akurat, cepat dan relevan. Rancangan sistem meliputi rancangan model organisasi, rancangan input, proses dan output, rancangan algoritma, Data Flow Diagram (DFD), rancangan basis data dan rancangan prototype. Rancangan model dibatasi pada semua informasi yang berhubungan dengan Sistem Informasi Program UKS. Rancangan input, proses dan output sistem untuk menjelaskan proses dari sistem informasi Program UKS di Dinas Kesehatan Kabupaten Purwakarta. Rancangan algoritma dirancang untuk memperlihatkan urutan instruksi yang digambarkan dengan simbol-simbol tertentu pada tahap input, proses dan output dari sistem informasi UKS. Data Flow Diagram untuk melihat aliran data dan entitas yang terkait dalam pengembangan sistem.

Rancangan basis data untuk memenuhi kebutuhan informasi yang sesuai dengan aplikasi yang akan digunakan, memudahkan pemahaman terhadap struktur informasi dan memberikan keterangan tentang persyaratan pemrosesan dan kemampuan dari sistem pengolahan data. Pada rancangan basis data file-file yang berhubungan diuraikan dalam kamus data yang terbagi dalam tiga file utama terdiri dari file master adalah file data yang berisi data puskemas, data desa, data sekolah, data status sekolah dan jenis sekolah, file transaksi adalah file data yang berisikan data hasil kegiatan UKS, penjaringan kesehatan dan keadaaan UKS dan file laporan adalah file keluaran yang akan ditampilkan dari sistem ini, seperti laporan kegiatan penjaringan kesehatan dan keadaan UKS dan tabel relasi. Berdasarkan hasil rancangan secara umum dan terinci maka dihasilkan rancangan prototype terbagi ke dalam struktur menu dan desain prototype.

Rancangan algoritma yang dikembangkan dalam sistem informasi UKS terdiri dari 3 rancangan algoritma sesuai transaksi yang dilakukan pada sistem informasi UKS yaitu register UKS, penjaringan kesehatan dan keadaan UKS.

Data Flow Diagram dalam Sistem Informasi UKS digambarkan sebagai berikut : (a.) Diagram Context (Lihat gambar 1). (b.) DFD Level 0 (Lihat gambar 2) (c.) DFD Level 1 (Lihat gambar 3)

\section{Pembahasan}

Kegiatan pengumpulan data UKS berasal dari kegiatan penjaringan kesehatan dan pembinaan kesehatan yang dilakukan pada anak usia sekolah oleh puskesmas. Sasaran pembinaan UKS meliputi pendidikan TK/RA, SD/MI, SMP/MTS dan SMA(K)/MA. Untuk proses pengumpulan, pengolahan dan analisis data, diperlukan peningkatan kualitas pengelola program dalam memanfaatkan sarana dan teknologi pendukung yang ada, mengingat hampir setiap puskesmas sudah mempunyai komputer. Sistem informasi UKS diharapkan dapat memudahkan pengumpulan, pengolahan dan analisis data kegiatan UKS. Pembiayaan mencakup pembiayaan pelaksanaan kegiatan UKS dan pembiayaan pengembangan dan pemeliharaan sistem. Proses suatu sistem meliputi pengolahan dan analisis data yang dipengaruhi oleh kualitas data yang dipengaruhi pengelola program yang perlu mendapat pelatihan tentang pengolahan dan analisis data.

Indikator yang digunakan dalam program UKS mengacu kepada penjaringan atau pemeriksaan kesehatan 
Gambar 3. Data Flow Diagram (DFD) Level 1

DFD LEVEL 1

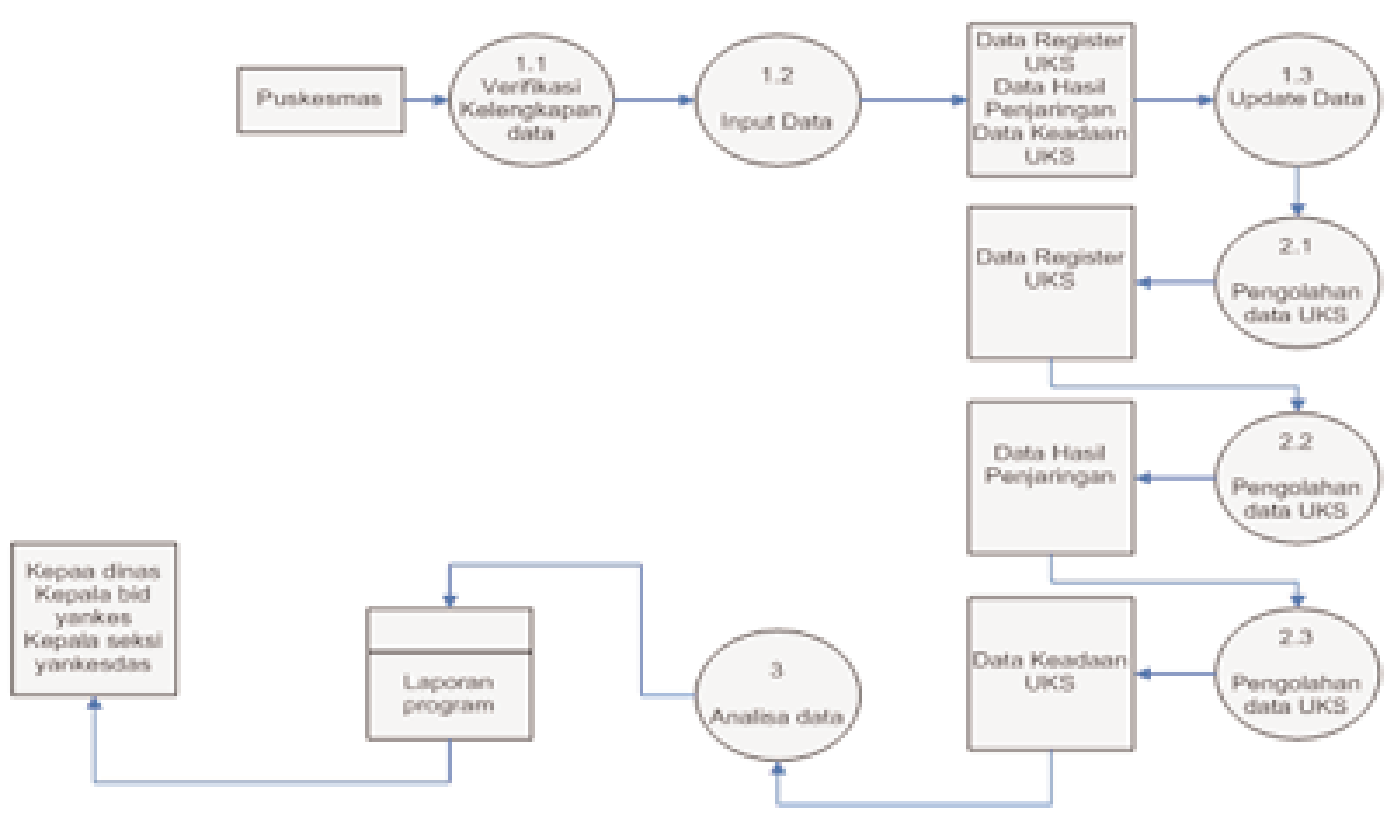

Tabel 2. Perbandingan Sistem

\begin{tabular}{|c|c|c|}
\hline Tahap & Sistem Lama & Sistem Baru \\
\hline Input & $\begin{array}{l}\text { Data Puskesmas diperoleh melalui laporan kegiatan penjaringan } \\
\text { dan pembinaan sekolah yang dicatat dalam buku visum atau } \\
\text { buku bantu lainnya. Format berbeda yang tidak saling } \\
\text { mengakomodasi akan menyebabkan kerancuan dan kebingungan } \\
\text { dalam pengisian data. Register UKS tak tersedia sebagai data } \\
\text { dasar dan alat bantu perhitungan indikator UKS Program } \\
\text { aplikasi memakai Microsoft Excel. }\end{array}$ & $\begin{array}{l}\text { Data puskesmas yang diperoleh melalui laporan kegiatan penjaringan } \\
\text { kesehatan dan pembinaan sekolah disimpan dalam data base aplikasi } \\
\text { Sistem Informasi UKS. Program aplikasi memberikan kemudahan } \\
\text { mengisi dua format yang berbeda karena telah mengakomodasi } \\
\text { kedua format tersebut. Register UKS tersedia dalam aplikasi sehingga } \\
\text { mempermudah melihat pencapaian dan perhitungan indikator UKS. } \\
\text { Program aplikasi menggunakan MS Visual Basic } 6.0 \text { dengan data base } \\
\text { menggunakan acces yang diharapkan memudahkan pemeliharaan. }\end{array}$ \\
\hline Proses & $\begin{array}{l}\text { Pencatatan dan pelaporan kegiatan UKS masih bersifat manual } \\
\text { dan tidak seragam. Pelaporan yang tidak teratur dan kesulitan } \\
\text { dalam melakukan umpan balik. }\end{array}$ & $\begin{array}{l}\text { Pencatatan dan pelaporan kegiatan UKS mengarah kepada sistem } \\
\text { komputerisasi. Laporan yang masuk akan terpantau sehingga } \\
\text { merangsang laporan yang teratur dan memudahkan dalam umpan balik. }\end{array}$ \\
\hline Output & $\begin{array}{l}\text { Laporan penjaringan kesehatan dan keadaan UKS dibuat secara } \\
\text { terpisah. Perhitungan indikator dihitung secara terpisah. } \\
\text { Penyajian tabel dan grafik membutuhkan proses agak lama. }\end{array}$ & $\begin{array}{l}\text { Laporan penjaringan dan keadaan UKS dibuat dalam satu aplikasi } \\
\text { Perhitungan beberapa indikator dapat diperoleh langsung dari laporan } \\
\text { penjaringan dan keadaan UKS. Penyajian tabel dan grafik dapat dilakukan } \\
\text { dengan lebih cepat dengan melakukan ekspor dari tabel yang dibutuhkan. }\end{array}$ \\
\hline
\end{tabular}

dan keadaan UKS. Berdasarkan prototype sistem informasi UKS yang dikembangkan, laporan penjaringan kesehatan UKS menyajikan formulasi hasil penjaringan UKS antara lain: cakupan sekolah dan cakupan murid yang mendapat penjaringan kesehatan, proporsi status gizi proporsi murid dengan status, proporsi murid dengan tes kesegaran jasmani, proporsi murid dengan hasil pemeriksaan, proporsi murid dengan kasus penyakit. Laporan keadaan UKS dapat menyajikan tentang cakupan sekolah UKS, sekolah dengan guru UKS, sekolah dengan kader UKS, proporsi sekolah dengan dana sehat, proporsi sekolah dengan TP UKS, cakupan murid UKS, proporsi kader UKS yang dilatih, cakupan kader UKS seluruhnya, proporsi guru UKS yang dilatih, proporsi KIT UKS, cakupan imunisasi anak sekolah dan proporsi sekolah dengan paket pelayanan UKS.

Sistem yang baru perlu dikembangkan untuk meme- 
cahkan permasalahan-permasalahan yang timbul, meraih kesempatan-kesempatan yang ada atau memenuhi instruksi yang diberikan. Penyempurnaan dalam sistem baru antara lain memodifikasi perbedaan format dalam pelaporan kegiatan UKS antara pemegang program UKS dan laporan SP3, memberikan kemudahan dalam pencatatan dan pelaporan kegiatan UKS, memberikan kemudahan dalam perhitungan indikator UKS. Untuk itu disajikan perbedaan sistem lama dan sistem baru. (Lihat Tabel 2)

Sistem Informasi UKS merupakan sebuah program aplikasi yang ditujukan untuk administrasi dan pengelolaan program Usaha Kesehatan Sekolah (UKS) di dinas kesehatan. Hal tersebut dapat mempercepat proses pengolahan data dan memudahkan pengukuran indikator pelayanan kesehatan kegiatan UKS. Program aplikasi ini menggunakan aplikasi Microsoft Visual Basic 6.0 dengan database menggunakan Microsoft Acces. Dalam kesiapan implementasi pada sebuah sistem ini mempunyai kelebihan dibandingkan dengan sistem yang ada sekarang antara lain : (a) Program aplikasi memberikan kemudahan pengisian format UKS yang dikelola program UKS atau kegiatan UKS pada laporan SP3 karena telah mengakomodasi kedua format tersebut. (b) Tersedia register UKS dalam aplikasi sehingga memudahkan melihat pencapaian dan perhitngan indikator UKS. (c) Program aplikasi menggunakan MS Visual Basic 6.0 dengan database yang menggunakan acces, diharapkan memudahkan pemeliharaan karena aplikatif dengan MS office yang banyak digunakan dalam komputer. (d) Perhitungan beberapa indikator dapat dilakukan langsung dari laporan penjaringan dan keadaan UKS. (e) Penyajian tabel dan grafik dapat dilakukan secara lebih cepat dengan melakukan ekspor dari tabel keadaan UKS dan penjaringan UKS.

Namun demikian, pengembangan sistem informasi UKS tersebut masih terdapat kekurangan yang membutuhkan penyempurnaan. Kelemahan dalam sistem ini antara lain : (a) Penyajian tabel dan grafik indikator UKS masih harus melalui ekspor sehingga membutuhkan kegiatan pengolahan lanjutan. (b) File laporan yang terlalu panjang perlu dipecah sehingga dapat sesuai dengan ukuran kertas. (c) Program aplikasi UKS ini dapat diterapkan di puskesmas, tetapi pengiriman data masih harus manual karena tidak tersedia fasilitas transfer data seperti backup dan restore.

\section{Kesimpulan}

Dari hasil penelitian ini disimpulkan (1) Identifikasi masalah dalam sistem informasi UKS di Kabupaten Purwakarta ditemukan permasalahan pada setiap tahap mulai input, proses sampai output. Adanya permasalahan pada sistem ini mengakibatkan pelaksanaan manajemen UKS termasuk intervensi program UKS tidak optimal. (2) Pengembangan sistem informasi UKS di Dinas Kesehatan Kabupaten Purwakarta menggunakan metode System Development Life Cycle (SDLC), yang dirancang dengan basis data dan output sistem sesuai kebutuhan yang dapat menunjang manajemen UKS dalam perencanaan, pelaksanaan penggerakan, pengawasan, pengendalian dan penilaian program UKS termasuk intervensi program secara tepat, cepat, akurat dan relevan. (3) Keunggulan sistem yang dikembangkan pada sistem informasi Usaha Kesehatan Sekolah (UKS) berbasis database management system (DBMS) dengan menggunakan program Microsoft Visual Basic 6.0 dan database Microsoft Access diharapkan memberikan kemudahan dalam input data, didesain otomatisasi dalam perhitungan, kecepatan dalam pengolahan data menjadi informasi dan akurasi data berdasarkan basis data yang digunakan, memberikan informasi program UKS berdasarkan updating data yang dilakukan sesuai dengan kebutuhan. (4) Sistem ini menghasilkan pelaporan dan informasi indikator program yang lengkap, cepat dan akurat sesuai kebutuhan. Juga dilengkapi dengan sistem ekspor data yang memungkinkan data dapat diolah dengan aplikasi lain yang kompatibel.

\section{Saran}

Puskesmas sebagai sumber data sebaiknya mendapat feedback dan disupervisi secara berkala minimal sekali dalam tiga bulan untuk kelengkapan data dan ketepatan waktu laporan baik dari puskesmas ke kabupaten maupun dari kabupaten ke propinsi. Sumber daya tenaga pengelola program UKS perlu mendapatkan pelatihan dan pembinaan yang intensif dalam peningkatan cakupan program UKS dan pemanfaatan aplikasi ini sehingga bermanfaat dalam peningkatan akurasi dan kelengkapan data dan mendorong kinerja dan manajemen program UKS. Supaya sistem infomasi ini bisa diterapkan di Dinas Kesehatan Kabupaten Purwakarta maka perlu sosialisasi pada user dan tingkat manajemen serta diadakan pelatihan terlebih dahulu bagi user dan penanggungjawab analisis program UKS sebelum dioperasionalkan. Selain itu, harus didukung oleh sarana dan dana yang memadai. Untuk mengimplementasikan sistem diperlukan kondisi ideal sistem supaya dapat berjalan dengan optimal, maka perlu dilakukan evaluasi dan monitoring untuk perbaikan dan pengembangan sistem berikutnya sesuai dengan siklus hidup sistem sehingga sistem yang dikembangkan ini menjadi lebih sempurna. Aplikasi ini dapat dikembangkan lebih lanjut dalam desain prototype sehingga dapat diperoleh penyajian yang lebih sempurna. Aplikasi sistem informasi ini dapat dijadikan model bagi pengembangan sistem informasi UKS di kabupaten lain dengan kondisi yang sama di wilayah Indonesia. 


\section{Daftar Pustaka}

1. Depkes RI (2004a). Petunjuk Teknis Standar Pelayanan Minimal Bidang Kesehatan di Kabupaten/Kota . Jakarta.

2. Depkes RI (2004b). Pedoman Pelaksanaan Pendidikan Keterampilan
Hidup Sehat (PKHS) bagi Petugas Kesehatan. Jakarta.

3. Depkes RI (2003d).Usaha Kesehatan Sekolah : Petunjuk Teknis Penjaringan Kesehatan Anak di Sekolah. Jakarta.

4. BAPEDA \& BPS (2005). Purwakarta dalam Angka 2004. Purwakarta. 